\title{
Kontrowersyjne porozumienie armeńsko-tureckie z 10 października 2009
}

Najstarsze wiadomości o Armenii pochodzą sprzed mniej więcej 2,5 tys. lat. Starożytni mieszkańcy tej zakaukaskiej krainy mówili językiem z wielkiej rodziny indoeuropejskiej i określają do dzisiaj samych siebie bardzo starym terminem „Haj”, który zapewne etymologicznie wiąże się z imieniem legendarnego protoplasty narodu ormiańskiego Hajka. W pierwszych latach IV wieku Armenia stała się krajem chrześcijańskim, a sto lat później mnich Mesrop Masztoc opracował oryginalny alfabet ormiański, którym zaczęto spisywać literaturę: początkowo tłumaczoną z obcych języków (Biblia), później - rodzimą. Tak więc Ormianie są narodem starożytnym o wielowiekowej tradycji własnej odrębności, z której każdy Ormianin czuje się dumny. W XI wieku znaczna część historycznej Armenii znalazła się pod panowaniem Turków seldżuckich, którzy przybyli wtedy na Bliski Wschód z Azji Środkowej. Turecka dominacja nie doprowadziła jednak do asymilacji Ormian, którzy pozostali wierni swej religii i kulturze. Pod koniec XIX wieku wśród Ormian mieszkających w Turcji zaczęły dojrzewać ambicje niepodległościowe. Spotkały się one z represjami ze strony władz tureckich. Kulminacją tych prześladowań była przeprowadzona w czasie I wojny światowej (poczynając od 24 kwietnia 1915) masowa eksterminacja ludności ormiańskiej określana obecnie niemal powszechnie terminem „ludobójstwo" (po ormiańsku: ceghaspanutiun, po angielsku: genocide) ${ }^{1}$. Liczba ofiar tej masakry osiągnęła przerażającą liczbę półtora miliona zmarłych i zabitych Ormian. Wschodnia część Armenii (z Erywaniem jako późniejszą stolicą niepodległego państwa) do początków XIX wieku pozostawała pod władzą Persji obecnie zwanej Iranem. W roku 1828 Rosjanie zdobyli na Persach Erywań i północna część tzw. ,perskiej Armenii” znalazła się pod panowaniem Imperium

${ }^{1}$ Zob. Y. Ternon, Ormianie. Historia zapomnianego ludobójstwa, przekł. W. Brzozowski. Kraków 2005. 
Rosyjskiego, a później - Związku Radzieckiego. Upadek tego państwa w 1991 roku umożliwił powstanie niepodległej Republiki Armenii obejmującej teren zaledwie jednej dziesiątej części historycznej Wielkiej Armenii.

Początki niepodległego bytu Republiki Armenii były bardzo ciężkie. Doszło do wojny z sąsiadem od wschodu - Azerbejdżanem. Powodem tego konfliktu był sprzeciw Azerbejdżanu wobec decyzji władz ormiańskiego Autonomicznego Obwodu Górskiego Karabachu (po ormiańsku: Lernajin Gharabaghi Inknawar Marz) stanowiącego część terytorium Azerbejdżańskiej SRR o połączeniu się z macierzystą Armenią. W trakcie tych krwawych starć władze tureckie zamknęły w 1993 roku granicę turecko-armeńską, wspierając tym samym bratni Azerbejdżan, którego ludność mówi językiem zbliżonym do tureckiego i wyznaje islam podobnie jak większość obywateli Turcji. Po zawieszeniu działań wojennych w 1994 roku na froncie armeńsko-azerbejdżańskim stosunki armeńsko-tureckie pozostawały napięte w zasadzie aż do ubiegłego (2008) roku. Jednakże trwające od piętnastu lat zamknięcie granicy dzielącej oba państwa stawało się elementem coraz bardziej niekorzystnym

Armenia jest obecnie krajem pozostającym w znacznej izolacji od reszty świata. Granice od wschodu (zAzerbejdżanem) i zachodu (z Turcją) pozostają zamknięte, a granica północna (z Gruzją) po wojnie gruzińsko-rosyjskiej z sierpnia 2008 roku przestała być w pełni pokojową granicą, bowiem władze gruzińskie zaczęły mieszkających na południu Gruzji (w Dżawachetii) Ormian traktować jako niemal „piątą kolumnę” wrogiej Rosji i poddawać ich asymilacyjnym naciskom. Te z kolei sprawiają, że mieszkający w Dżawachetii Ormianie dążą do przyłączenia tego terytorium do Armenii. Jedynie krótki odcinek południowej granicy oddzielającej Armenię od Iranu funkcjonuje normalnie i umożliwia wzajemną komunikację i wymianę handlową. Tak więc jedynym sąsiadem, z którym Armenia pozostaje w dobrych stosunkach, jest Islamska Republika Iranu.

Wzrastająca zależność gospodarcza i finansowa Armenii od Rosji przyczynia się do ubożenia szerokich warstw społecznych Armenii, które do pewnego stopnia są zainteresowane otwarciem granicy z Turcją. Handel przygraniczny mógłby bowiem poprawić sytuację materialną wielu Ormian. Z kolei Turcja aspiruje, choć bynajmniej niejednomyślnie, do połączenia się z Unią Europejską, która wywiera na ten kraj naciski, by podniósł on m.in. standardy demokratycznych zachowań wobec swoich mniejszości etnicznych. Obecnym władzom tureckim bardzo zależy w związku z tym na załagodzeniu konfliktu z wielomilionową mniejszością kurdyjską. Również uregulowanie stosunków z Armenią, która marzy o umocnieniu związków z Europą (i pewnym uniezależnieniu się od Rosji), byłoby przez Zachód odebrane bardzo pozytywnie, posuwając w jakimś stopniu do przodu trudny proces integracji Turcji z Unią Europejską. Tak więc w obu krajach, w Armenii i w Turcji, umacniały się w ostatnich latach tendencje do nawiązania stosunków dyplomatycznych i otwarcia granicy. Sprzyjały 
temu także naciski Stanów Zjednoczonych (a może i Rosji), których dyplomacja zabiegała o podjęcie przez oba zwaśnione kraje rokowań. Nietypowym elementem tego zbliżenia była tzw. polityka footballowa. 6 września 2008 roku w Erywaniu odbył się mecz piłkarski drużyn Armenii i Turcji. Nie tyle wynik spotkania był tu ważny (wygrali Turcy), co obecność na meczu dwóch prezydentów: Armenii Serża Sarkisjana oraz Turcji Abdullaha Güla. Skoro do meczu doszło, to znaczy, że jakiś postęp we wzajemnych, nieoficjalnych na razie kontaktach został dokonany. Od początku 2009 roku trwały negocjacje armeńsko-tureckie, które zaowocowały uzgodnieniem dnia 31 sierpnia tego roku wstępnego porozumienia.

I wreszcie 10 października 2009 roku w szwajcarskim Zurychu ministrowie spraw zagranicznych obu krajów (Armenii Edward Nalbandian i Turcji Ahmet Davutoğlu) podpisali dwa protokoły: o ustanowieniu stosunków dyplomatycznych i o rozwoju stosunków dwustronnych ${ }^{2}$. Przy podpisaniu obu dokumentów zwanych łącznie „porozumieniem” (po ormiańsku: hamadzajnagir) obecni byli m.in. sekretarz stanu USA Hilary Clinton, szef unijnej dyplomacji Javier Solana, a także minister spraw zagranicznych Federacji Rosyjskiej Siergiej Ławrow. Porozumienie to toruje drogę do otwarcia granicy turecko-armeńskiej, które miałoby przypieczętować zbliżenie nie tylko w sferze symbolicznej, ale także praktycznie. Porozumienie z Zurychu czeka teraz na ratyfikację przez parlamenty obu krajów. Tu jednakże mogą się pojawić (i już się pojawiają) trudności.

Światowe środki masowego przekazu, w tym także polskie, powitały na ogół przychylnie owo porozumienie, widząc w nim wyraźny krok w stronę pełnej normalizacji stosunków pomiędzy sąsiadującymi ze sobą krajami, które raczej dzieli niż łączy trudna historia dotychczasowych kontaktów. Jednakże tego samego dnia, kiedy w Szwajcarii uroczyście podpisywano w świetle reflektorów protokoły torujące, zdawałoby się, bezproblemowo drogę do pojednania obu narodów, w Libanie katolikos Aram I, drugi pod względem prestiżu po katolikosie eczmiadzyńskim Gareginie II zwierzchnik Apostolskiego Kościoła Ormiańskiego, wygłosił orędzie, w którym zdecydowanie potępił owo porozumienie. Trzeba pamiętać, że w ciągu wieków tureckiego i perskiego panowania nad Ormianami wytworzyła się tradycja przyznająca katolikosom, czyli patriarchom narodowego Apostolskiego Kościoła Ormiańskiego (niezależnego od Rzymu i od Cerkwi prawosławnych), zwyczajowe prawo reprezentowania narodu ormiańskiego. Tak więc głos Arama I nie był tylko jego prywatną opinią interesującą wyłącznie wyznawców Apostolskiego Kościoła Ormiańskiego, lecz niezwykle ważnym głosem diaspory ormiańskiej, którą patriarcha Wielkiego Domu Cylicji (tak brzmi oficjalny tytuł Arama I) w znacznym stopniu reprezentuje. Zabierając oficjalnie głos, Aram I miał za sobą bardzo mocne poparcie ormiańskich środowisk emigracyjnych,

\footnotetext{
${ }^{2}$ W. Górecki, Kaukaz, „Nowa Europa Wschodnia” 6 (2009), s. 10.
} 
które od Bliskiego Wschodu aż po Kalifornię od dawna już przestrzegały rząd w Erywaniu przed zawieraniem porozumienia dyplomatycznego z Turcją. Może niekoniecznie jakiegokolwiek porozumienia, ale takiego, przed którym strona turecka nie uznałaby faktu ludobójstwa popełnionego na ludności ormiańskiej w Turcji w latach I wojny światowej. Dla diaspory ormiańskiej, która wywodzi się głównie z uchodźców z terenów ogarniętych w 1915 roku masakrami, sprawa ma zasadnicze znaczenie ${ }^{3}$. Bowiem do tej pory żaden rząd turecki nie uznał za ludobójstwo tego, jak wówczas postąpiono w Turcji z Ormianami. Według strony tureckiej, owszem, wielu Ormian w owych latach zginęło (liczbę ofiar zaniża się przy tym niekiedy do około 300 tys.), ale nie w następstwie jakiejś planowanej przez rząd turecki akcji, lecz w następstwie działań I wojny światowej, od których ucierpiała cała ludność Turcji, a nie tylko Ormianie. A tu właśnie ani w samych protokołach, ani wcześniej w jakimkolwiek innym dokumencie tureckim sprawa wydarzeń z 1915 roku w ogóle nie została poruszona. Była to cena, jak się zdaje, zbyt wygórowana za zawarcie porozumienia na zasadzie pewnego kompromisu. Strona ormiańska przystała na pozostawienie (na razie) na boku do badań historyków sprawy ludobójstwa z 1915 roku, a strona turecka odstąpiła (być może tylko czasowo) od popierania Azerbejdżanu w konflikcie o Górski Karabach, który władze w Baku chciały odzyskać, korzystając m.in. z poparcia bratniej (w sensie etnicznym i religijnym) Turcji.

Warto tu przypomnieć (zwłaszcza tym najbardziej nieprzejednanym zachodnioormiańskim krytykom porozumienia), że już następnego dnia po jego zawarciu władze Azerbejdżanu ostro potępiły podpisanie obu protokołów, dopatrując się w tym akcie znacznego osłabienia swych szans na odzyskanie Górskiego Karabachu.

Krytyczne stanowisko diaspory ormiańskiej wobec porozumienia z Zurychu sprowadza się do następujących punktów:

1) Tylko zachodni Ormianie, potomkowie uchodźców z Turcji (a nie wschodni, z części Armenii podległej dawniej Rosji) są pełnoprawnymi depozytariuszami sprawy ludobójstwa z 1915 roku;

2) Rząd w Erywaniu nie ma moralnego prawa do zawierania porozumienia z Turcją w imieniu całego narodu ormiańskiego, którego większość mieszka jakoby poza Republiką Armenii. Propagandowo zawyża się przy tym wielkość diaspory ormiańskiej do niesprawdzalnej liczby ośmiu (!) milionów osób (wobec niespełna trzech milionów mieszkańców Republiki Armenii).

Takie stanowisko zdecydowanie odrzucające porozumienie z 10 października 2009 roku jest wśród diaspory ormiańskiej powszechne. Według raportu PISM-u aż 90 proc. Ormian mieszkających w USA potępia podpisanie protokołów

\footnotetext{
${ }^{3}$ Por. L. Ritter, Ormiańskie losy. Historia i przyszłość diaspory, przekł. z jęz. fr. R. Stryjewski, Warszawa 2009.
} 
z Zurychu. Również w samej Republice Armenii negatywne stanowisko w tej sprawie jest dość częste, ale zwykle przybiera bardziej zniuansowaną postać. Oto np. katolikos eczmiadzyński Garegin II w zasadzie popiera nawiązanie stosunków dyplomatycznych z Turcją i otwarcie granicy armeńsko-tureckiej. Sprzeciwia się jednak spychaniu na dalszy plan sprawy ludobójstwa popełnionego na Ormianach w Turcji w czasie I wojny światowej. Obstaje także przy zapewnieniu niepodległości Górskiemu Karabachowi zwanemu przez wielu Ormian według starożytnej tradycji Arcachem. Także sympatycy partii Dasznakcutiun, którzy podjęli po podpisaniu porozumienia w Zurychu protestacyjny strajk głodowy w centrum Erywania, nie domagali się zerwania porozumienia, a jedynie wniesienia do protokołów pewnych poprawek.

W Republice Armenii daje się zapewne odczuwać presja psychologiczna ze strony radykalnej diaspory typu: nie godzi się z niskich pobudek materialnych (perspektywy handlu z Turkami po otwarciu granicy) „zaprzedawać” świętej sprawy godności narodowej, jaką jest pamięć o Ormianach bestialsko zamordowanych lub zmarłych z głodu i od chorób podczas deportacji do Syrii, jaką wobec Ormian zarządziły w 1915 roku władze tureckie ${ }^{4}$.

Postawa sprzeciwu jest również zróżnicowana wewnętrznie w obrębie diaspory. Katolikos Aram I nie określa prezydenta Armenii Serża Sarkisjana mianem „zdrajcy”. Na drugim biegunie znaleźli się wcześniej demonstranci to właśnie słowo (po zachodnioormiańsku: tawadżan) wykrzykujący pod adresem Sarkisjana podczas jego podróży, którą odbył na początku października do Paryża i Kalifornii. W środowiskach emigracyjnych prezydent Republiki Armenii usiłował załagodzić nastroje sprzeciwu wobec zbliżającego się podpisania porozumienia z Turcją. Niektórzy Ormianie francuscy kładli się na ziemi przed pomnikiem ofiar ludobójstwa w Paryżu, by uniemożliwić Sarkisjanowi złożenie kwiatów. Demonstrantów rozpędzała francuska policja. Ormianie zachodni przesyłali sobie pocztą elektroniczną karykatury przedstawiające ministra spraw zagranicznych Armenii jako karła stojącego na stoliku obok potężnego, uzbrojonego Turka, który go upokarza. Nie brakowało głosów typu: „politycy z Erywania sprzedali się za jeden mecz piłkarski”.

Z punktu widzenia neutralnego obserwatora sceny wewnątrzormiańskich sporów niemal jednogłośne potępienie omawianego tu porozumienia może się wydawać przesadną reakcją nieprzejednanego środowiska, które nie jest w ogóle zainteresowane jakąkolwiek ugodą z wrogą stroną. Spróbujmy jednak dla lepszego zrozumienia tego typu postaw wyobrazić sobie paralelę polską. Byłby nią np. ewentualny traktat kładący kres wielowiekowym konfliktom Polski z Rosją, w którym tragedia katyńska pozostawiona byłaby na boku tylko

\footnotetext{
${ }^{4} \mathrm{O}$ wadze problemu ludobójstwa w środowiskach diaspory ormiańskiej wiele pisze Laurence Ritter w swej znakomitej rozprawie Ormiańskie losy. Historia i przyszłość diaspory, Warszawa 2009.
} 
do „badań historyków” mających sprawdzić, kto właściwie i w którym roku dokonał mordu na tysiącach polskich oficerów w czasie II wojny światowej. Dla znacznej liczby Polaków taki traktat byłby również nie do przyjęcia.

Spójrzmy także na turecki punkt widzenia, w którym na brak wiedzy o tym, co się działo z tzw. osmańskimi Ormianami w czasie I wojny światowej, nakłada się bliższa czasowo pamięć o aktach zemsty dokonywanych przez terrorystów ormiańskich w latach 1973-1983. Szkoleni w obozach dla palestyńskich terrorystów bojownicy organizacji ASALA czy też zwolennicy partii Dasznakcutiun zabili wówczas około pięćdziesięciu Turków, głównie dyplomatów pracujących w ambasadach i konsulatach tureckich. W zamachu bombowym na lotnisku Orly pod Paryżem w 1983 roku zginęło dwóch Turków i kilku przedstawicieli innych narodowości.

Terroryści ormiańscy wywodzili się głównie z krajów arabskich. Można się więc zastanawiać, czy na ich decyzje co do metod działania nie wywarł wpływu radykalizm niektórych środowisk muzułmańskich w pełni aprobujących terror jako uprawnioną metodę walki z Zachodem traktowanym jako główny wróg islamu. Zdaniem wielu muzułmanów bojownicy o sprawę uważaną za świętą nabierali prawa do dysponowania życiem „osób trzecich” (a więc np. niewinnych pasażerów porwanego samolotu) z tej racji, że sami gotowi byli oddać życie za „świętą sprawę”, np. w razie niepowodzenia akcji porwania samolotu dla wymuszenia uwolnienia aresztowanych przez ,imperialistów” współuczestników walki. Z poglądami takimi stykałem się w Iranie jeszcze na parę lat przed wybuchem rewolucji (1979), bo już w 1973 roku. Właśnie wtedy, gdy mieszkający w Kalifornii Ormianin Kurken Janikian zastrzelił konsula tureckiego, mszcząc się w ten sposób za śmierć przeszło dwudziestu swoich ormiańskich krewnych zabitych przez Turków w 1915 roku.

Ten i inne zamachy dokonane przez Ormian w latach 1973-1983 były aktami symbolicznymi obliczonymi na zmuszenie władz tureckich do uznania faktu ludobójstwa z 1915 roku. Oczywiście cel ten nie został zrealizowany. Co więcej, dostarczył antyormiańsko nastawionym politykom tureckim argumentów za usztywnieniem stanowiska wobec Ormian. Zaczęto na przykład wytwarzać materiały mające wykazać nieznającym historii cudzoziemcom (i własnej młodzieży) rzekomo odwrotny charakter konfliktów etnicznych z czasów I wojny światowej. Zdaniem autorów takich materiałów Ormianie mieli mordować na wielką skalę Turków.

W Polsce kilka lat temu jedna $\mathrm{z}$ gazet rozpowszechniała płytę $\mathrm{z}$ turecką reklamą turystyczną zawierającą m.in. 50-minutowy antyormiański film propagandowy, w którym obok prawdy o ofiarach tureckich z lat 1973-1983 zamieszczone były wyjątkowo cyniczne kłamstwa o wydarzeniach 1915 roku. A 11 maja 2005 roku w trakcie sesji zatytułowanej Ludobójstwa i czystki etniczne w XX wieku, która odbyła się w Warszawie pod patronatem Studium 
Europy Wschodniej Uniwersytetu Warszawskiego dla uczczenia „90. rocznicy ludobójstwa Ormian w 1915 roku w ottomańskiej Turcji” został wyświetlony negacjonistyczny film turecki pt. Tragedia ludzkości w XX wieku.

Stosunki ormiańsko-tureckie nie zawsze jednak kształtują się tak brutalnie „czarno-biało” (czy z drugiej strony „biało-czarno”). W ostatnich latach wraz z tendencją władz tureckich (chodzi głównie o rządzącą obecnie Partię Sprawiedliwości i Rozwoju - Adalet ve Kalkınma Partisi) do zakończenia krwawego konfliktu z Kurdami pojawiły się także próby poprawy stosunków z Ormianami. W roku 2008 grupa intelektualistów tureckich zainicjowała akcję zbierania podpisów pod swojego rodzaju internetowymi przeprosinami skierowanymi do Ormian. Ten ważki tekst nie zawierał wprawdzie budzącego kontrowersje terminu „ludobójstwo” lecz „tylko” sformułowanie „wielka katastrofa” (po turecku: büyük felâket), niemniej jednak był tekstem, który mógł dać pewną satysfakcję ormiańskiej opinii publicznej. Oto tekst tego dokumentu, który do lipca 2009 podpisało w Turcji ponad 30 tys. osób:

„Moje sumienie nie zgadza się z brakiem współczucia widocznym w postawie zaprzeczania faktowi Wielkiej Katastrofy, której ofiarą padli osmańscy Ormianie w roku 1915. Potępiam tę niesprawiedliwość i staram się wczuć w ból i cierpienie moich ormiańskich braci i sióstr. Przepraszam ich"'.

Ten niewątpliwie szlachetny krok został jednak w jakiejś mierze zdezawuowany przez wypowiedź prasową tureckiego politologa B. Orana, który oświadczył: „Pan premier powinien nam dziękować za tę kampanię. Na całym świecie parlamenty uchwalały, $i$ to automatycznie, rezolucje. Teraz ten proces się zatrzyma. Diaspora mięknie. Międzynarodowe środki przekazu zaczęły odchodzić od używania terminu ludobójstwo"6.

Ostatni szczegół wskazuje na to, jak bardzo subtelną materię stanowi spór ormiańsko-turecki o przeszłość i... przyszłość. Gdy już się wydaje, ze nastąpił krok we właściwym kierunku i faktyczne porozumienie będzie możliwe, nagle jakiś element utrudnia dalszy postęp.

Wygląda na to, że podobna sytuacja zaistniała jesienią 2009 roku. Z wielkim trudem dyplomatów wielu krajów udało się doprowadzić do podpisania w Zurychu porozumienia, a tego samego dnia spotkało się ono ze zdecydowaną krytyką ze strony wspomnianego wyżej dostojnika Apostolskiego Kościoła Ormiańskiego. W parę dni po 10 października otrzymałem drogą elektroniczną wraz z propozycją podpisania tekst petycji powstałej w środowisku francuskich Ormian. Apelują oni o wyrażanie podpisem poparcia dla przedstawionych w petycji treści. Apelują do Ormian, a także do wszystkich osób, „dla których

${ }^{5}$ Cyt. za: N. Szahnazarian, Jeśli otworzysz czterdzieste drzwi. Tureccy intelektualiści wobec akcji przepraszania Ormian, „Biuletyn Ormiańskiego Towarzystwa Kulturalnego” 58/59 (2009), s. 27.

${ }^{6}$ Tamże, s. 34 
godność ludzka stanowi wartość”. Petycja zawiera treści zbliżone do tego, co powiedział w swym orędziu katolikos Aram I. Zawarty jest jednak w niej także pewien postulat, który mnie jako naukowca zaszokował. Oto mianowicie jeden z punktów petycji orzeka, że... nie ma prawa podejmowania badań nad dziejami ludobójstwa popełnionego na Ormianach w Turcji w 1915 roku taki historyk, który by z góry nie uznał faktu owego ludobójstwa. Autorzy petycji powołują się przy tym na analogiczny postulat stawiany jakoby badaczom Zagłady Żydów (Szoa) z lat drugiej wojny światowej. Tego rodzaju żądanie jest sprzeczne z istotą nauki, która poszukuje prawdy bez... warunków wstępnych.

Niektórzy publicyści zachodnioormiańscy wypowiadają gorzkie opinie, że Turkom udało się skłócić Ormian, „wbić klin” między Republikę Armenii a diasporę. Nawet przyjmując taką optykę, trzeba jednak przyznać, że skrajne postawy części diaspory owo „wbijanie klina” znacznie ułatwiły.

Spróbujmy przedstawić prognozy dalszego rozwoju wypadków wokół granicy armeńsko-tureckiej. Nie można wykluczyć, że po pewnym czasie emocje opadną i zachodni Ormianie pogodzą się ze zbliżeniem między Erywaniem a Ankarą. Nikt z diaspory nie będzie przecież jeździł nad rzekę Achurian, która dzieli Republikę Armenii od Turcji, po to, by pikietować tę granicę i uniemożliwiać podróżowanie Ormianom do Turcji i Turkom do Armenii. Możliwe jest jednak również, że różnice poglądów między tymi Ormianami (niemal wyłącznie „Wschodnimi”), którzy nie bez zastrzeżeń, ale jednak popierają porozumienie z 10 października 2009 roku, a tymi (głównie poza granicami Armenii), którzy owo porozumienie opatrują epitetem „haniebne”, będą się na tle emocjonalnym pogłębiały, co doprowadzi do długotrwałego rozłamu w obrębie jednego narodu.

By to lepiej zrozumieć, wyobraźmy sobie społeczeństwo polskie, które pod zaborami przeżyło nie „tylko” 123 lata (jak to miało miejsce w rzeczywistości), ale 600 lat, bo taki mniej więcej okres dzieli upadek ostatniego państwa średniowiecznej Armenii (Królestwo Cylicji) od odzyskania przez ten kraj niepodległości pod koniec XX wieku. Z pewnością różnice w mentalności i tradycjach Polaków $\mathrm{z}$ zaboru pruskiego byłyby mocno różne od tych z zaboru rosyjskiego.

Nie można też wykluczyć jeszcze innej możliwości. Jeśli protesty przeciw porozumieniu nie osłabną, parlamenty mogą nie ratyfikować porozumienia z 10 października 2009. Dotyczy to obu krajów.

Na początku 2010 roku sprawa uległa dalszym komplikacjom. Armeński Trybunał Konstytucyjny 12 stycznia 2010 roku uznał za konieczne przed ewentualną ratyfikacją porozumienia przez parlament wprowadzenie pewnych uzupełnień do tekstu podstawowego. Na to strona turecka zareagowała uzależnieniem ratyfikacji porozumienia z 10 października 2009 roku przez parlament turecki od uregulowania przez Armenię i Azerbejdżan sprawy Górskiego Karabachu. To stanowisko potwierdził premier Turcji Recep Tayyip Erdoğan, o czym doniosła, 
powołując się na AFP, prasa polska 19 kwietnia 2010 roku$^{7}$. Jeśli wziąć ponadto pod uwagę wypowiedzi niektórych publicystów z diaspory ormiańskiej (dla nich traktat Zuryski jest „haniebny”) uważających, że już można wrócić do dialogu wewnątrzormiańskiego nadszarpniętego porozumieniem, które faktycznie jest... nieporozumieniem, to można wyrazić obawę, że dokument podpisany jesienią 2009 roku będzie jeszcze długo miał wartość „listu intencyjnego”.

\section{Summary}

The controversial Armenian-Turkish agreement of 10 October 2009

On 10 October 2009 in Zurich, Switzerland, the ministers of foreign affairs of Armenia and Turkey signed two protocols: on establishing diplomatic relations and on the development of bilateral relations. Figures such as, e.g. United States Secretary of State Hilary Clinton, EU foreign policy chief Javier Solana as well as Russian Minister of Foreign Affairs Sergey Lavrov were present at signing both documents jointly called an agreement. The agreement undoubtedly paved the way for the opening of the Armenian-Turkish border, which would be of both practical and symbolic significance. The agreement is awaiting ratification by the parliaments of both countries. There are, however, some difficulties which at the same time allow to determine the agreement in question as controversial. First of all the matter of argument between the parties being acknowledgement of the genocide of Armenians of 1915 by Turkey. The lack of references to the event in the document signed in Zurich brought about a wave of criticism amongst Armenian emigration, which simultaneously showed profound differences between the Eastern Armenians, inhabiting the Republic of Armenia, and the emigration.

Translated by Joanna Malak

${ }^{7}$ W skrócie. Europa. Granica Turcji z Armenia będzie nadal zamknięta ..., „Rzeczpospolita” z 19 kwietnia 2010. 
